\title{
ARISTOTLE ON MORAL AND ECONOMIC CRISES
}

\begin{abstract}
The 24 centuries that separate us from Aristotle despite the historical world changes that have occurred in the meantime, have by no means tarnished the value of his suggestions for to curing the ills that strike human societies.
\end{abstract}

Keywords: Aristotle, corruption, crisis, judgement, justice, mendiety, value, virtue.

The Aristotelian value of mediety has often been transgressed during the last decades by competent authorities in economy and finance. It is due to their actions that the crisis which today plagues our societies has derived. What kind of treatment would Aristotle have suggested in this case? I shall try to explore, among the Stagirite's doctrines, how he would conceive the problems of our human present and what processes he would recommend in order to solve them.

Aristotle's Politics, combined with his Ethics, furnish us with precise indications on the causes of the calamities that be set mankind in its quasi totality. The disequilibrium between technological evolution, developing exponentially, and the shortfall of education in the field of the humanities and of culture stresses the distinction, of Aristotelian origin, between the mentalities of the slave and the master. Aristotle says that the slave is deprived not of reason ${ }^{1}$ but only of the faculty of deliberation, which is acquired thanks to education, to which capital importance is assigned (at the end of the Politics) ${ }^{2}$. Consequently, the slave is incapable of setting as the aim of his life what is beyond his immediate needs for his survival, in contrast with the free citizen, who goes forward to the pursuit of fur-

${ }^{1}$ Cf. Politics, a 13, 1260 b 5-6.

${ }^{2} \mathrm{Cf}$. ibid, mainly in books $\Theta$ and $\mathrm{I}$. ther aims that presuppose the former aims as the means for their accomplishment. This difference becomes decisive as regards the weaknesses of the slave group, who depend on the representatives of the citizen group, able to activate themselves and to manage money in order to enrich themselves. This allows them at least, to hire the services of the slaves, when to not exploiting them. Nevertheless, the economic development of individuals, reflected in the well-beng of the whole city, has its limits. Here again the value of mediety is to be considered. The continuous economic development of some cities suffers due to the behavior of their public authorities, which act as if they were dominated by a mentality becoming to slaves. More precisely, they are exclusively interested in perspectives of immediate gain and not in longer-term, and no doubt not exclusively financial ones. They do not even think to take advantage of their city's actual wealth, not as a purpose in itself, but as a means of reaching more distant aims, such as real and lasting happiness ${ }^{3}$, leaving aside a tendency of administrators to seek for quick profile, honors and other personal advantages. Instead, their major care ought to be to respect the city's laws without ever diverging from them ${ }^{4}$. Such respect is a supreme virtue that per-

\footnotetext{
${ }^{3}$ Cf. ibid, A 1, 1252 b 29-30.

${ }^{4}$ Cf. ibid, Г 4, 1277 b 24-26; Г 13, 1283 a 39-40.
} 
mits, without any impediment, the well-being of all the citizens, the optimal and ultimate purpose of life ${ }^{5}$.

A useful administrator governs virtuously, and in keeping with justice. His or her dominant virtue is prudence equivalent to sagacity, and complementing it, without, of course, being identifiable with it. According to the philosophy of kairicity, prudence consists in foreseeing, in patiently waiting and in acting at the night time. One can now understand the importance of Aristotle's formulation. What follows will be no more than footnotes.

After 1973, China opened herself to foreign investment, and American capital flooded the Far East while the American market was inundated by cheap products that weakened the industry of the New World. China, in fact, still holds the major part of American public shares. The American administration has had recourse to printing paper money without restraint, not directly, but through private institutions, and satisfied banking with a low percentage as taxation, while various owners of capital have recourse to their tax havens. The American example has been followed by the rich countries of the Eurozone, which have invested their capital in countries with suitable production costs, and underdeveloped and weakly governed, Greece as well. She has been deprived of means of development, and, of course, of the right to print paper money, while grants, salaries and gratifications of every kind have dizzily multiplied, with tragic results due to the preference of successive governments for chosen categories of citizens. In December 2000, a law was voted in the United States, whereby banking institutions were allowed to act independently of public administration. I was deeply impressed by a recent statement from a representative of PIMCO, one of the peak American financial organizations: «We have enough speculated about Europe; the moment of truth has come». These predictions of the crisis now hitting our societies eluded the parti-

${ }^{5}$ Cf. Eudemian Ethics, A 5, 1216 a 19-27. sans of globalization, who turned a blind eye, and by politicians, who proved to be all for of a voluntary serfdom.

How would Aristotle have evaluated the present crisis? From an etymological viewpoint, the

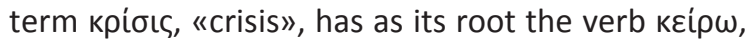
"shear», closely linked to the Homeric adjective

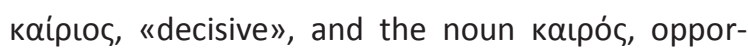
tune moment. It is, therefore, easily understandable that my interest in the meaning of the term crisis is closely linked to the notion of kairicity, which remains so important to me.

The essential character of every crisis is that it marks a discontinuity within a continuity. Every crisis can be foreseen, but at the beginning is confronted with the indifference, habit. Its evident cause is an exaggerated overrun of Aristotelian mediety, a üßpıৎ, «arrogance», which inevitably,

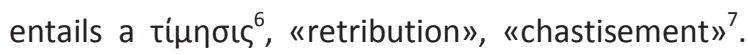
No crisis appears invisibly. It is just stated

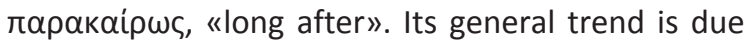
to its opposition to continuity. Aristotle cleverly compares it to the correspondence of the legs, while the individual is in motion ${ }^{8}$. A lack of correspondence would result from the acceleration of one leg while walking, while the speed of the others remains unchanged, the result being a sliding that, mutandis mutatis, might remind us of Bergson, and the insidious effect on those present, of «something mechanical plated upon something live» ${ }^{9}$. It is a momentary sliding, since it allows the accident to stand up again, fairly promptly ${ }^{10}$. All this was al-

${ }^{6}$ Cf. Polit., E 8, 1308 b 2 and 6.

${ }^{7}$ Cf. ibid, Z 4, 1319 a 19.

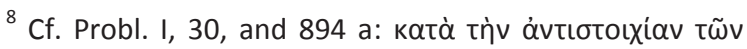

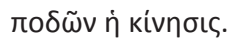

${ }^{9}$ Cf. On walking of animals, 8, 708 a 11 - b 8; 13; 15; 31. Cf. H. Bergson, Le rire, Paris, Alcan, 1900, p. 29; CEuvres, Paris, P.U.F., 1959, p. 403.

${ }^{10}$ On laughter in comedy, cf. Poetics, 4, 1449 a 34: (the

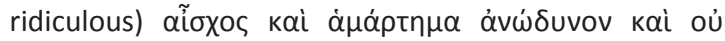

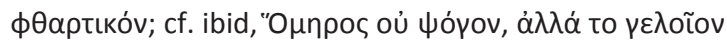

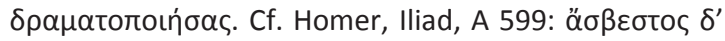


ready envisaged by Aristotle in his Physics, and I shall not dwell on it. It will be sufficient to refer to the crisis of values and the degradation of the virtues that correspond to them.

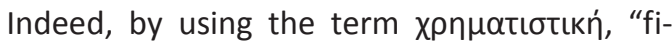
nancial administration" (Polit., A 3, 1253 b 14; 9, $1257 \mathrm{~b}$ 18), instead of the term oikovouia used by Plato (Republic II, 402 b; VI, 408 a; Laws III, 694 c; VII, 819 a-e) and Xenophon (Oecon., 1, 1), Aristotle innovates in order to stress the distinction between the administration of family funds and public ones, finance. Let me recall Protagoras' motto: $\pi \alpha \dot{v} \tau \omega \nu$

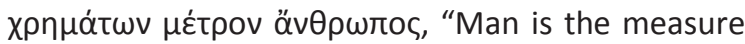
of everything" (D.-K. Vors.16, fr. B 110, II, 263, 3-5), a relativistic device par excellence, where $\chi \rho \tilde{\mu} \mu \alpha$, "means of exchange of goods", etymologically re-

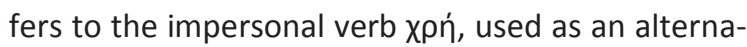
tive to $\delta \varepsilon \tilde{\imath}$, "it is necessary". Aristotle's innovation is that here, instead of an egalitarian distribution of goods, as conceived by Plato in his Republic VII, 558 c, he adopts a fiscal model parallel to the judicial one where the egalitarian distribution of goods and charges is completed by a corrective process. His thinking about these issues is scattered throughout the Nicomachean Ethics and the Politics. I shall try to gather together in categories, so to be able to draw certain conclusions in about how Aristotle would have confronted a crisis similar to the one we are actually experiencing, mutandis mutatis again.

In principle, a crisis has a duration within a certain time. It sometimes reaches a peak before it fades away, not without having left some wounds. However, such a peak contains several other peaks. In his Physics, Aristotle mentions days of crises ${ }^{11}$, establishing the concept of crises within crises $^{12}$.

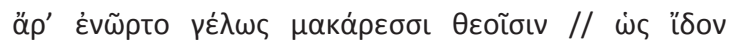

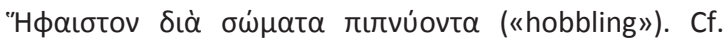

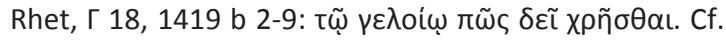
Plato, Cratylus, 425 a.

${ }^{11}$ Cf. Phys., E 6, 230 b 5.

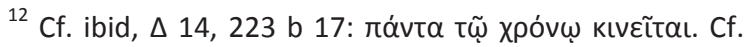

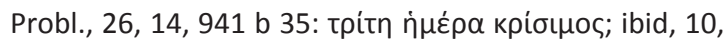

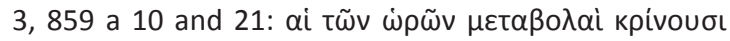

One, can equally ask whether crises of habits and of values that provoke economic crises as the symptoms are not themselves social diseases needing appropriate treatment. It is clear that within each kairos there are now various microkairoi within the principal crisis.

On the other hand, a kpiors in the sense of "judgment", is not only an element expressing a thought; it is the manifestation of the mental function by which one judges the truth or the falsehood of one's thoughts ${ }^{13}$. Such a kpioıs is essentially a discrimination between different themes ${ }^{14}$, but it is also a statement about the affinity of "things of a kind"15. As judgment, крíбıৎ presupposes a criterion, which refers, in the case of situations, to a mental measure, but in the case of e.g. sense objects to former experience ${ }^{16}$. The same occurs in the case of humors $^{17}$ and of what is tangible ${ }^{18}$, the tongue being the organ which is criterion of the taste ${ }^{19}$. For each isolate case ( $\kappa \alpha \theta^{\prime}$ हैк $\left.\alpha \sigma \tau \alpha\right)$, experience requires a more general criterion, so that the appropriate ${ }^{20}$ judgment can be understood and above all be controlled as clear and correct; in other words, as not admitting any contest ${ }^{21}$. As for judgements ${ }^{22}$ on differential, even of animals, exactitude is to be stated, even if it is not required ${ }^{23}$. Discrimination and exactitude are also required when stating the difference between identity and similarity ${ }^{24}$. In the

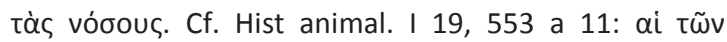

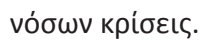

${ }^{13}$ Cf. De anima, Г 3, 428 a 3.

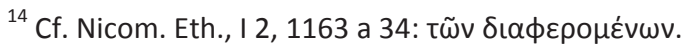

15 Ibid.

${ }^{16}$ Cf. Metaph., K 6, 1063 a 3.

${ }^{17}$ Cf. Nicom. Eth., Г 13, 1118 a 28.

${ }^{18}$ Cf. Phys., $\Delta$ 8, 216 b 19.

${ }^{19} \mathrm{Cf}$. On the parts of animals, $\Delta 5,678 \mathrm{~b}$ 8; Hist. of animals, $\Delta 8,535$ a 11

${ }^{20}$ Cf. Nicom. Eth., $\Delta 11,1126$ b 4.

${ }^{21}$ Cf. ibid, H 2, 1237 b 12.

${ }^{22}$ Cf. Rhet., Г 12, 1417 b 24.

${ }^{23}$ Cf. Gener. Of animals, E 2, 781 b 2.

${ }^{24}$ Cf. Polit., $\Delta$ 11, 1295 a 34; Phet. B 23, 1398 b 19. 
tonger perspective, under test conditions a judgment represents a distinction between the just and the unjust ${ }^{25}$.

It is only after this step that justice is established $^{26}$. Prudence is called for the judge or judges in order not to be misled by inexactitudes and by consciously untrue testimonies ${ }^{27}$, let alone constantly necessary populist harangues ${ }^{28}$. Criteria are, therefore constantly ne-cessary, so that the judges shall not be influenced by rhetoric tending to act upon their affectivity ${ }^{29}$ and to incite them to erroneous judgments able to be naive, if not childish ${ }^{30}$.

I have sufficiently insisted on the term crisis as designating a mental process, in order to clarify that such a process constitutes an act of controlled choice $^{31}$.

The prudence of the city's administrators, together with kairicity intentionally experienced by them, is the manifestation of a mediety expressed by the temporal adverbs not yet and nevermore. Imprudence, on the other hand, qualifies decisions taken by the authorities too early or too late or even inconsiderately, and entailing for the city calamities unforeseen avoided by spasmodic measures that, in the long run, prove useless. The question then arises: how are these people to be punished, since the legislation they have themselves instituted sanctifies their misdeeds ${ }^{32}$ ? The responsibility will be shifted downwards, to the general from the particular or vice versa ${ }^{33}$, according to the interest not of the city ${ }^{34}$, but of the cul-

\footnotetext{
${ }^{25}$ Cf. Nicom. Eth., E 6, 1134 a 31; Rhet., B 4, 1377 b 21.

${ }^{26}$ Cf. Polit., B 8, 1268 b 5; $\Delta$ 16, 1300 b 34; E 6, 1306 a 37.

${ }^{27}$ Ibid, B 5, 1263 b 21.

${ }^{28}$ Ibid, E 6, 1305 b 35.

${ }^{29}$ Cf. Rhet., B 1, 1378 a 21.

${ }^{30}$ Cf. Polit., B 9, 1271 a 10.

31 Ibid, Z 7, 1321 a 30.

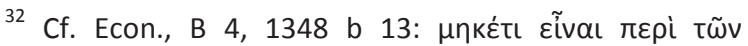

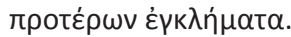

${ }^{33}$ Cf. Polit., Г 15, 1286, a 27.

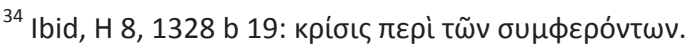

prits themselves ${ }^{35}$. Even the ephores may be classified into the category of culprits, in spite of the fact that they are supposed to oversee prominent cases

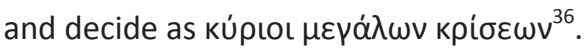

At this point I have to stress the importance Aristotle gives to the notion of autarky. For him an

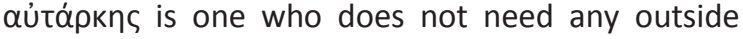
assistance or voluntarily have recourse to it, if able to survive without too much joint action. Such an attitude presupposes the possibility of drawing on excessive resources, but also the exhaustion of any

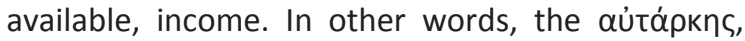
the "self-sufficient" one is he who cares for mediety; that is, the right middle, avoiding either the too much or its excessive opposite ${ }^{37}$. Autarcy is a value to cultivate $^{38}$; a value of the same importance as that of the perfect good which is selfsufficient $^{39}$. In the animal kingdom we find species which revel in autarky ${ }^{40}$.

At a human level the issue becomes more complicated. The slave, for instance, deprived of freedom and depending on his master, is also deprived of autarcy ${ }^{41}$. Aristotle blames Plato for not having sufficiently insisted on this ${ }^{42}$. He even adds that a city deprived of autarcy also risks falling into dependence. As regards cities, the underlying postulate here is mediety. By analogy, even kings cannot reign if deprived of autarcy ${ }^{43}$. The same applies

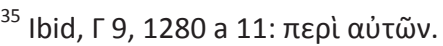

${ }^{36}$ Ibid., B 9, 1270 b 28 and 29.

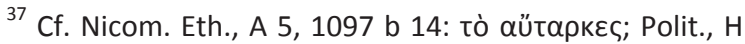
5, 1326 b 30; Rhet., A 7, 1364 a 8.

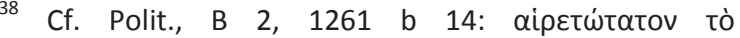

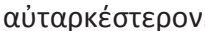

${ }^{39}$ Cf. Nicom. Eth., a 5, 1097 b 8; Rhet., A 6, 1362 a 27.

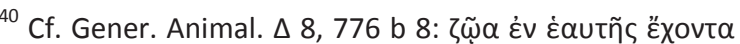

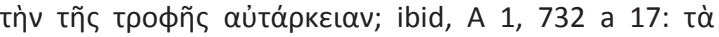

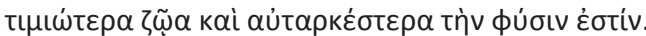

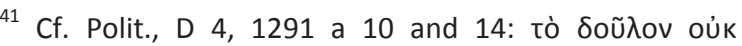
$\alpha$ $\tau \alpha \rho \kappa \varepsilon \varsigma$

${ }^{42}$ Cf. Plato, Republic II, 369 b-e.

${ }^{43}$ Cf. Nicom. Eth., $\Theta 12,1160$ b 4.
} 
to anyone who does not live with dignity ${ }^{44}$. Like the Good itself, autarcy contributes to the happiness resulting from a contemplative life ${ }^{45}$. Man needs an autarcy of life ${ }^{46}$ which is for the virtuous citizen an aim in itself and indeed the best one ${ }^{47}$. The autarcy of possessing ${ }^{48}$ is therefore a substitute for natural autarcy ${ }^{49}$. In any case, human life remains the best and the most perfect one, provided it is crowned by autarcy $y^{50}$. For this reason, in any choice or selection, preference goes to whoever displays the greatest autarcy $^{51}$.

As for the wise man, the latter meets his needs to the highest degree, precisely thanks to his wisdom, which allows him to revel his happiness and beatitude ${ }^{52}$. An ascending hierarchy of human autarcies is to be noticed here A single person may be self-sufficient, but his family has to be more so, and still more the curry ${ }^{53}$. The underlying postulate of mediety, is once more again applied here. In order to remain self-sufficient and prosperous, the city should not see its population at once grow excessively, due to a rush of rural populations towards urban centers or to a flood of metrics, but should develop gradually and regularly, so that it does not exceed at any time a certain limit clearly and prudently defined in advance. The city's institution has to provide the $\varepsilon \tilde{u} \zeta \tilde{n} v$ "the well-being" of the citi$z^{2} s^{54}$ and consequently to be itself strong ${ }^{55}$ from

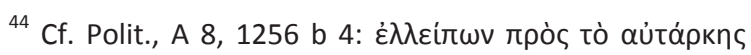
हĩval.

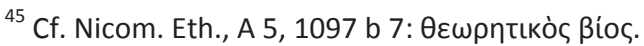

${ }^{46}$ Cf. Rhet., A 5, 1360 b 15; Polit., 「 1, 1379 b 21:

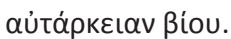

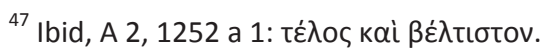

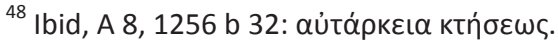

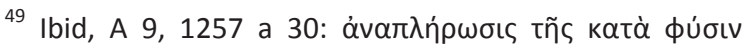

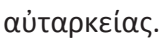

${ }^{50}$ Ibid, Г 9, 1280 b 34; 1281 a 1.

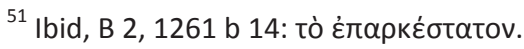

${ }^{52}$ Cf. Nicom. Eth., H 12, 1244 d 3-6; 19, 1969 b 3-5; K 7; 1573 b 1.

${ }^{53}$ Cf. Polit., $\Delta$ 2, 1253 a 23; B 2, 1261 b 11.

54 Ibid, B 2, 1261 a 25; 「 6, 1278 b 16; 9, 1280 a 31 and b 30. the virtue of the inhabitants ${ }^{56}$. In case of default, it will lose of its autarcy. The city of Athens developed thanks to its miniature colonial and imperialist "alliances", through which it appropriated the resources of its "allies". Alexander the Great, Aristotle's pupil, on the other hand, creatively propagated Hellenism and its culture, while destroying Greece itself, in the view of the German historian Droysen ${ }^{57}$. Though exaggerated, this indigent contains a nucleus of truth.

If citizen virtue has as its result the well-being of the city, citizen corruptibility, open or hidden, contributes to its weakness. Aristotle seems to define corruption as entailing death ${ }^{58}$ and as a calamity $^{59}$ nurtured by cupidity, generally at the expense of the community ${ }^{60}$ and mediated by bribery ${ }^{61}$ or merely by accepting a tip, which is still a kind of injustice towards the city. The most numerous and the most disposed to succumb to such a temptation are those who occupy, even temporarily, a public position; for example, decision, makers ${ }^{62}$ or those whose opinion is taken seriously, such as doctors ${ }^{63}$ or other specialists ${ }^{64}$. Particularly, vulnerable to bribery are the people in long-term positions ${ }^{65}$. Cupidity is accompanied by avidity. "The appetite of pleasure is greedy for it $^{\prime 66}$, declares the founder of the Lyceum, who condemns avidity of any kind,

${ }^{55}$ Ibid, H 1, 1323 b 34.

${ }^{56}$ Ibid, H 1, 1323 b 34.

${ }^{57}$ Cf. H. G. Dreusen, Alekander der Große, 1833.

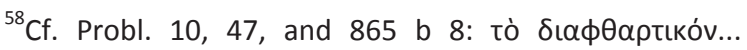
Өavatnфópov.

${ }^{59}$ Cf. Metaph, ๑ 9, 1051 a 21.

${ }^{60}$ Cf. Polit., $\Delta$ 12, 1297 a 11; E 3, 1302 b 9; Nicom. Eth., I 6, 1167 b 11 .

${ }^{61}$ Ibid, $\Theta 16,1163$ b 11; fr. 374, 1540 b 2.

${ }^{62}$ Cf. Rhet., A 12, 1372 a 34.

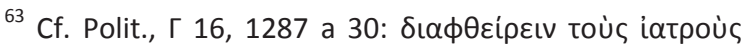

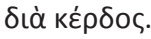

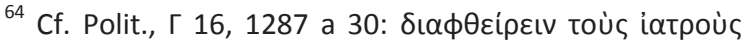

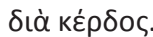

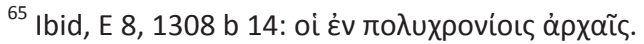

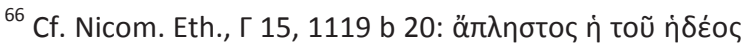

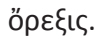


such as the insatiability of human indolence ${ }^{67}$ and of desire ${ }^{68}$, the desire to experience at any cost a voluptuous life of debauch, a life qualified by imprudence and lack or moderation, typical of those who flaunt their status of wealthy parvenus or behave thus according to circumstances ${ }^{69}$, especially dignitaries in long-term positions ${ }^{70}$.

Insatiability and corruption "for profit" are excesses in the exercise of power, üßpعıৎ, specific

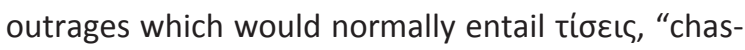
tisement", "payment". The term tíoıৎ suggests, whether etymologically or not, the other terms,

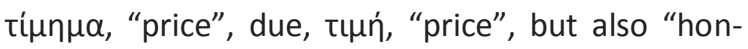

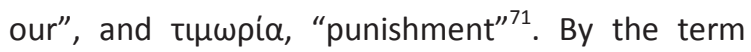

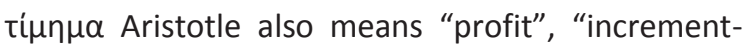
value", "interest"72. However the same term applies also to special contributions such as the poll tax (haraç in Turkish), exacted by the Ottoman administration from non-Muslims, which in today's Greek designates a supplementary tax supposedly temporary, but, in fact, permanently incorporated into the tax system.

In the Politics, unlike those deprived of fortune $^{73}$, those who are wealthy and fortunate must pay a tribute ${ }^{74}$ to the city in the form of a donation $^{75}$ scaled to their taxable wealth in each case ${ }^{76}$. It is from those with most wealth - (unless they deliberately fail to declare...) that the dignitaries of the city are to be nor ably side by side with members of illustrious families and notably virtuous citi-

\footnotetext{
${ }^{67}$ Cf. Polit., B 7, 1267 b 2.

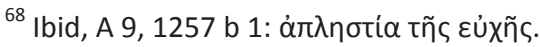

${ }^{69}$ Cf. supra, n. 60.

${ }^{70}$ Cf. supra, n. 65.

${ }^{71} \mathrm{Cf}$. the latin timor, «fear».

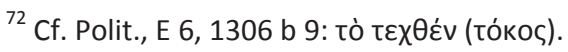

${ }^{73}$ Ibid, Г 12, 1253 a 11.

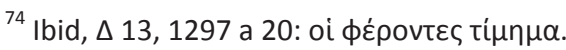

${ }^{75}$ Ibid, $\Delta 15,1300$ a 10.

${ }^{76}$ Ibid, B 7, 1266 b 23; 「 5, 1278 a 23; $\Delta 4,1291$ b 3; E 7, 1307 a 28.
}

zens $^{77}$. Nevertheless, possible modification of the rate of taxes to pay may entail trouble and changes to a city's constitution ${ }^{78}$.

A similar danger had been foreseen by the Pythagorean thinker Damon of $\mathrm{Oa}$, who predicted that moving away from traditional musical laws could entail constitutional changes. During his trial before the Athenian Areopagus in 443 B.C., he defended his views, but was sentenced to exile. His teaching was venerated by Plato ${ }^{79}$ and, to some degree, by Aristotle $^{80}$.

Let us stay with Aristotelian concepts of crises of various kinds in order to study his criticism of Plato's, egalitarian conception of the tax burden on the citizens of his Republic. As we have seen, Aristotle in his Politics constrasts equality and unfair le-velling. This distinction equates to his distinetion between the two levels of juridical order: distributive law, as complemented by corrective justice. Earlier, in the Topics ${ }^{81}$, it is said of legislation, as in Metaphysics of the being ${ }^{82}$, that justice can be un-

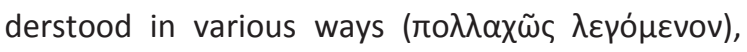
meaning that various legislations are conceivable. Thus, legislation is envisaged in two stages: isonomy, and adaptation of general rules to particular data, so that during the application of justice by the judges no injustice shall be committed. For him, justice is not alien to values and virtues: values such as the beautiful ${ }^{83}$; and all virtues ${ }^{84}$.

77 Ibid, $\Delta$ 15, 1300 a 10; Nicom. Eth., $\Theta$ 12, 1160 a 33: n̄

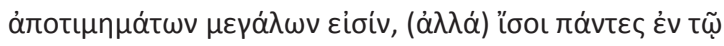

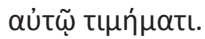

${ }^{78}$ Cf. Polit., E 8, 1308 a 35.

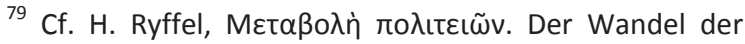
Staatsverfassungen, Noctes Romanae (Bern), 1949/2, pp. 23-38.

${ }^{80}$ Cf. Polit., $\triangle$ 3, 1290 a 19 ff.; $\Theta$ 5, 1340 b 7 ff.

${ }^{81}$ Cf. Topics, A 15, 1000 b 30; ๑ 3, 108 b 10.

${ }^{82}$ Cf. Motaph., Г 2, 1003 a 32; K 3, 1060 b 32; K 8, 1064 b 15.

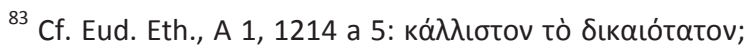

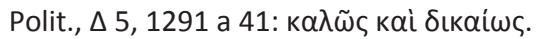

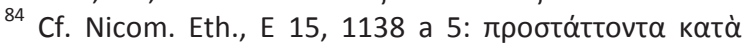

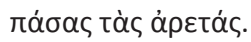


It is, isonomy that prevails in general ${ }^{85}$. The whole of the Fifth Book of the Nicomachean Ethics is an analysis of justice. Its two complementary aspects, distributive and corrective justice, distinct from each other, are treated separately; and then, in relation to each other. Distributive justice is governed by the mathematical ratio $4: 3^{86}$ whereas the harmonic ratio $3: 2$ is not mentioned, being obviously incompatible with the issue examined ${ }^{87}$. Corrective justice is alternatively designated as reparative justice $^{88}$. Egalitarian distribution presupposes, according, to Aristotle, the etymology of Síkatov, "law", "lawfulness", from the adverb six $\alpha$, "separately", "split in two" ${ }^{89}$.

Justice is animated by a judge ${ }^{90}$ who, in addi-

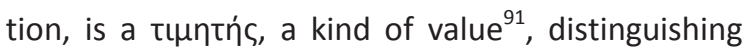
between natural and manmade law ${ }^{92}$. The main stem of justice speaks into an indefinite number of branches, to deal with which would take me beyond the scope of the present essay.

Returning now over the problem of contemporary global economic crisis, as Aristotle would, I think, have viewed $i^{93}$, we observe financial colossi which, through galloping technology, execute the orders of an economic oligarchy. Hence the globalization in which most of us, having adopted the Stouc notion of cosmoponlitanianism, had warily invested our hopes, today saturates our eyes and ears while stiffing our voices. These colossi however, have feet of clay. One of them has only to collapse, and all the others tremble and threaten to collapse in turn. Such a hypertsophisticated a system could not have been foreseen by Aristotle in

\footnotetext{
${ }^{85}$ Ibid, E 2, 1129 a 34; E 6, 1131 a 13; Polit., Г 9, 1980 a

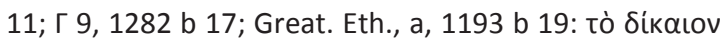

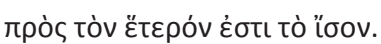

${ }^{86}$ Cf. Nicom. Eth., E 7, 1132 a 2 and 30.

${ }^{87}$ Cf. De anima, A 3, 406 b 29.

${ }^{88}$ Cf. Nicom. Eth., E 2, 1132 a 18; E 5, 1135 a 1-9.

${ }^{89}$ Ibid, E 2, 1132 a 32; b 32.

90 Ibid.

${ }^{91}$ Cf. Rhet. Alex., 5, 1427 b 6.

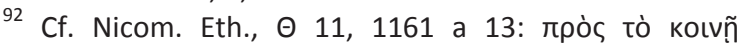
бu$\mu ф \varepsilon ́ p o v$.

93 Ibid, E 10, 1134 b 18 ff.
}

dreams ${ }^{94}$ his wildest. He considers the oikovó $\mu$ os as the administrator of the benefits of Nature to humankind ${ }^{95}$ and promotes him to the dignity of a governor ${ }^{96}$ bound to be $\alpha \dot{\gamma} \alpha \theta$ óc, "good" and "virtuous" as Nature herself who, on principle, eliminates, disperses and spoils nothing ${ }^{97}$. Man is not only a political ${ }^{98}$, but an economic, social ${ }^{99}$, even a combinatory ${ }^{100}$ animal. This means that he is able to organize his thought and behavior in keeping conformingly with his innate sense of the just and the unjust $^{101}$. He is aware in advance since he deliberates at leisure if he is committing an in justice, and that he will be charged as responsible for his action. The problem is then to decide which authority will charge him with it in due time (allusion to the notion of kairicity).

Aristotle does not reject, the term economic. He attributes it to humans as one of the principal characteristics of their life, contemplative or active, and "one of the most precious faculties of their spirit"102 provided, of course, that they employ it wisely, honestly and, above all, prudently, therefore in time $^{103}$ (still an allusion to the notion of kairicity). However, economy as an activity, is limited to the individual and the family ${ }^{104}$, though one can distinguish diverse species of economies, - the royal, satrapic, private and several others ${ }^{105}$. In the case of economic affairs of the city, a particular factor necessarily intervenes: chrematistics, the art of finance that deals with providing and managing the city's income ${ }^{106}$. Chrematistics develops methods of prac-

\footnotetext{
${ }^{94}$ Cf. Polit., A 10, 1058 a 25 ff; 「 11, 1282 a 21.

95 Ibid, A 10, 1258 a $31 \mathrm{ff}$.

${ }^{96}$ Cf. Gener. Of anim., B 6, 744 b 16.

${ }^{97}$ Cf. Polit., A 2, 1253 a 22.

${ }^{98}$ Cf. Eud. Eth., H 10, 1242 a 22.

${ }^{99}$ Ibid, H 10, 1242 a 26.

${ }^{100}$ Cf. Nicom. Eth., $\Theta ~ 14,1162$ a 17.

${ }^{101}$ Cf. Polit., A 2, 1253 a 16.

${ }^{102}$ Cf. Nicom. Eth., a 1, 1094 b 3.

103 Ibid, A 8, 1208 b 13.

${ }^{104}$ Cf. Polit., A 3, 1253 b 8; A 12, 1259 a 37; 「 14, 1285 b 32.

${ }^{105}$ Cf. Econ., B 1245 b 12 and 19-28.

${ }^{106}$ Cf. Polit., An 8, 1256 a 15.
} 
tical organization, and its ${ }^{107}$ definition and activities are given in the Politics ${ }^{108}$.

Хрп̃ $\mu \alpha$, "money", is understood in that case, as a common and stable means of exchanging goods ${ }^{109}$ or services. Money passes either from one person to another ${ }^{110}$ or from individuals to the city funds. In the second case the city's money is held sacred. This does not mean that money is never siphoned off from it for reasons of personal interest ${ }^{111}$. The city's money is regularly allocated after a budget, or exceptionally, to cover unforeseen ${ }^{112}$ expenses. Those who administer the finances are termed $\phi \iota \lambda о \chi \rho n-\mu \alpha \tau o \iota, ~ " m o n e y-l o v e r s " 113$, with all that this term implies about manipulation. Finally, Aristotle mentions two devices that are now common practice. One is, the arbitrary increase of money in circulation. This dates from the Bretton Woods Treaty $^{114}$, when the Gold standard was abandoned. We have recently been informed that the American administration will in the near future suspend printing of paper money. The other is the devaluation of money in circulation, due to its unconsidered increase and to the indirect revaluation, arbitrary too, of some other money, in this case the Chinese yu$\mathrm{an}^{115}$. The first possibility is tightly linked to its correlative, and it obviously entails the second. Aristotle already had these possibilities in mind. For him, on these issues, the prytaneis ${ }^{116}$ and the eponymous $\operatorname{archon}^{117}$ are supposed to be aware of their responsibilities and will have to decide.

Hence, the imperative questions are, how to prevent the embezzlement of public money ${ }^{118}$ or, if

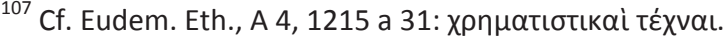

${ }^{108}$ Cf. Polit., an 8, 1256 a 1; an 11, 1259 b 36.

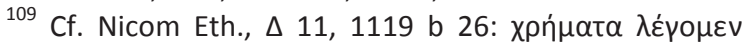

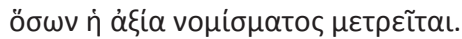

110 Ibid.

${ }^{111}$ Cf. Eudem. Eth., Г 4, 1231 b 37: icpá.

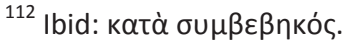

${ }^{113}$ Cf. Polit., E 12, 1316 a 40.

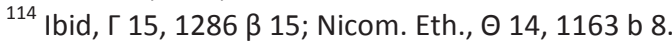

${ }^{115}$ Cf. Polit., a 9, 1257 b 34.

${ }^{116} \mathrm{Cf}$. Constit. Of the Athenians, 394, 1543 b 11.

117 Ibid, 381, 1511 b 20.

${ }^{118}$ Cf. Nicom. Eth., H 13, 1153 a 18.
}

not prevented in time (kairicity again!), how to punish it.

How can the pullers ${ }^{119}$ or their appointed mouthpieces accumulate rights and political advantages ${ }^{120}$ ? On this point the city's legislation admits of several corrections, in the form of complementary clauses ${ }^{121}$. The city should in such cases adopt dispositions that would exclude equity or clemency, as described in the Nicomachean Ethics $^{122}$, since this would be tantamount to perjury on part of high dignitaries ${ }^{123}$. Corruption is frequently organized in a criminal manner, with hierarchies and networks that hide from view, where the organizing minds plan undisturbed. Aristotle could not have imagined the development of the computer, where, with a single click, an immense sum of money can be transferred to some tax haven. From now on, equity and indulgence have no more part to play in justice, which will have to become inflexible. As globalization, by means of technology, has opened the way to the escape of capital, it will itself be obliged to restore that capital, albeit by severe measures against avoiders, and their families. It will suffice for alliances of interests to be stopped.

One hears continuous moans about horizontal cuts of salaries and pensions. Here again Aristotle offers a solution that could be adopted by administrative authorities. Instead of suppressing horizontal cuts, corrective law and other measures can be called in, to lighten the burden of victims of serious injustice.

Matandis mutatis, this would also apply to those who would have to pay a contribution ( envisages such payments ${ }^{124}$, but, at the same time,

${ }^{119}$ Ibid, 「 1, 1275 a 21; b 29; Z 1, 1317 a 35; Z8, 1321 b 21.

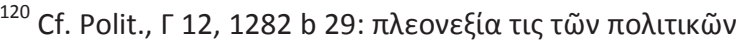

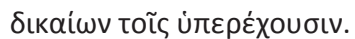

${ }^{121}$ Ibid, 「 1, 1275 a 21; b 29; Z1, 1317 a 35; Z 8, 1321 b 21.

122 Ibid, E 10, 1137 a $32 \mathrm{ff}$.

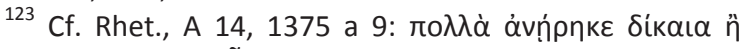

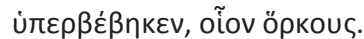

${ }^{124}$ Cf. Polit., E 11, 1313 b 20. 
envisages measures of relief for those who temporarily cannot meet their obligations ${ }^{125}$.

In addition to a minimal symbolic per capita, contribution of ${ }^{126}$, a farthing ${ }^{127}$ - each of Aristotle's citizens is asked to pay a sum he can afford, given his life standards (the famous indexes), individual and family needs, state of health, and so on, and to contribute objects of value ${ }^{128}$ and even, voluntarily, his whole fortune ${ }^{129}$, - at any rate, whatever he is willing to give ${ }^{130}$. Admittedly those who have neglected to pay their due will remain on tenterhooks, for their debt will always pursue them ${ }^{131}$. The same goes for those who neglect to restitute illegally exported money and exposed by informers. They will all know that they face a punishment in proportion to their misdeed ${ }^{132}$. This is what, for Aristotle, "saves the cities"133; at least, those cities whose governments are not implicated in circles' of corruption. They are mainly those whose judiciary authorities do not obstruct the processes of law by pretending a backlog of court cases and by expressing indignation for very substantial cuts in their salaries, during a period of economic crisis. They will be required to judge immediately, without any delays and without fear or favor. The status of the Aristotelian "perfect city" presupposes virtuous citizens and sanctions against corruption ${ }^{134}$ until it is wiped out completely thanks to an administration entrusted to virtuous citizens whose life is contemplative to the core.

It would be easy for me to prolong this argumentation ad infinitom. Instead, I shall end by affirming that the twenty four centuries which se-

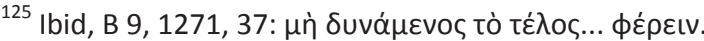

${ }^{126}$ Ibid, Г 9, 1280 a 20.

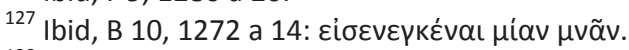

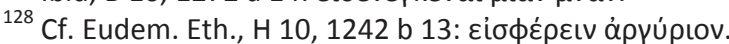

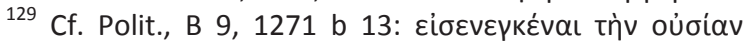

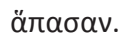

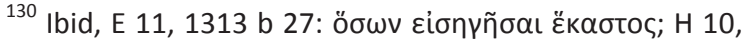
1330 a 4-7.

${ }^{131}$ Cf. Constits des Athémiens, 401, 1540 a 12.

${ }^{132}$ Cf. Neom. Eth., Г 11, 1117 a 14; E 8, 1131 b 21 and 23;

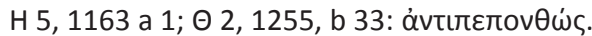

${ }^{133}$ Cf. Polit., B 2, 1261 a 30: $\sigma \omega \dot{\zeta \zeta \varepsilon ı ~ \tau \alpha ̀ ~ \pi o ́ \lambda \varepsilon เ \varsigma . ~}$

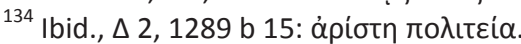

parate us from Aristotle, despite all important historical changes that have since occurred in human society, have in no way tarnished the value of his thoughts, and that his philosophy continues to be topical; so much so, that it gives us, some useful hints about how to use of the means and measures he proposes so as to cure the ills of human societies. We hope of course, that these means and measures will transform for the best a globalization that Aristotle had not foreseen. To him we can safely trust our aspirations our aspirations for a better future for humankind. 